PAEDAGOGIA ChRISTIANA

I/21 (2008) - ISSN 1505-6872

Elżbieta Sozańska*

Toruń

\title{
Zmiany w doradztwie pedagogicznym dla nauczycieli religii na przelomie tysiącleci
}

Współcześnie doradztwo stało się ważnym ogniwem pracy wielu instytucji i zostało wbudowane w ich struktury organizacyjne jako ważna komórka, zrzeszająca osoby podejmujące działania, korygujące i optymalizujące pracę zawodową ludzi ${ }^{1}$. Doradztwo pedagogiczne dla nauczycieli, jako forma wsparcia dla nauczyciela i pomoc $\mathrm{w}$ doskonaleniu zawodowym, liczy obecnie 90 lat. Pomimo tylu lat praktyki doradztwo pedagogiczne nie doczekało się pogłębionej refleksji pedagogicznej, w literaturze przeważają artykuły polemiczne, opisy zdarzeń $i$ analizy przepisów prawnych. Daje się odczuć brak refleksji filozoficznej czy antropologicznej tak powszechnego dziś zjawiska „doradztwa” nie tylko w oświacie. Niniejszy artykuł jest szkicem historycznym doradztwa przede wszystkim katechetycznego, poczynając od czasów po II wojnie światowej do współczesności oraz próbą wskazania kierunku zmian, jakie zachodzą w doradztwie katechetycznym.

\section{Ustalenie pojęć}

Interesująca jest sama analiza różnych ujęć terminu „doradztwo”. Pojęcie „doradztwo" jest równoznaczne z terminem „doradzanie”, pochodzącym od czasownika „doradzać”, co oznacza: „dawać rady, udzielać porady, wskazywać

${ }^{*}$ S. dr Elżbieta Sozańska USJK, jest wicedyrektorem Wydziału Katechetycznego Diecezji Toruńskiej, ekspertem MEN ds. awansu zawodowego oraz nauczycielem religii w Zespole Szkół nr 8 w Toruniu.

${ }^{1}$ Por. Cz. Maziarz, Agronomia społeczna, w: Elementy metodyki doradztwa rolniczego, Warszawa 1974 , t. 2 , s. $24-25$. 
sposób postępowania"2. Pogłębione rozumienie tego terminu podaje psychologia indywidualnego rozwoju ${ }^{3}$, która definiuje go, jako pomoc w opracowaniu programu konstruktywnej zmiany lub pomoc w osiaganiu wyższego poziomu kompetencji. Słownik indywidualnego rozwoju doprecyzowuje, że doradztwo to również pomoc w odszukiwaniu i nazywaniu wartości, określaniu rozmiaru wyzwań bądź pomoc w odczytaniu celów rozwoju. W takim rozumieniu pojęcia doradztwa, osoby doradcy nie można określać jedynie na podstawie wysokich kompetencji zawodowych czy profesjonalizmu. W tak rozumianym doradztwie istotne będą cechy osobowe doradcy, umiejętności komunikacji personalnej oraz sposób udzielania fachowych porad czy nawet instrukcji.

W oświacie doskonalenie zawodowe nauczycieli i doradztwo pedagogiczne mają ten sam cel, którym jest poprawa istniejącego stanu nauczania i wspieranie rozwoju nauczyciela ${ }^{4}$. Doskonalenie zawodowe przyczynia się do podniesienia kwalifikacji lub nadaniu nowych. Niemniej jednak udoskonalony nauczyciel nie przestaje doświadczać sytuacji trudnych, nowych i nieprzewidzianych doskonaleniem ${ }^{5}$. Dlatego proces doskonalenia zawodowego nauczycieli został wzbogacony o strukture doradztwa pedagogicznego. Jednakże współcześnie mianem doskonalenia i doradztwa określa się często działania wspierające nauczyciela w pracy edukacyjnej.

\section{Doskonalenie i doradztwo katechetyczne po II wojnie światowej}

Dewastacja kraju, zniszczone księgozbiory, znacznie uszczuplona kadra katechetyczna, jak również brak katechezy instytucjonalnej w czasie okupacji spowodowały, że w pierwszych latach po wojnie koncentrowano się wokół przezwyciężenia wyżej wymienionych trudności.

W dziedzinie wychowania dzieci i młodzieży przyjęto początkowo w kraju wszystkie akty prawne i zarządzenia z okresu międzywojennego, przede wszystkim Konstytucję z roku 1921 i umowę konkordatową z roku 1925․ Podstawowym zadaniem Kościoła w tym okresie stało się wznowienie systemu organizacyjnego katechezy szkolnej w kraju, w możliwie najefektywniejszym wymiarze. Pierwszoplanowym zadaniem było zatem zrekonstruowanie systemu nauczania religii na wszystkich szczeblach: krajowym, diecezjalnym i parafialnym.

${ }^{2}$ Por. H. Zagółkowa (red.), Praktyczny słownik współczesnej polszczyzny, t. 9, Poznań 1996, s. $144-145$.

${ }^{3}$ Por. W. Rachalska, Poradnictwo zawodowe, w: W. Szewczuk (red.), Encyklopedia psychologii, Warszawa 1998, s. 415-421; A. Reber, Stownik psychologiczny, Warszawa 2000, s. 523-524.

${ }^{4}$ Ministerstwo Edukacji Narodowej, $O$ doskonaleniu nauczycieli, Biblioteka Reformy nr 4, Warszawa 1999, s. 30.

${ }^{5}$ Por. D. Tripp, Zdarzenia krytyczne w nauczaniu. Ksztattowanie profesjonalnego osqdu, Warszawa 1996, s. 26-28.

${ }^{6}$ Por. J. Osuchowski, Państwo Ludowe a Kościół rzymsko-katolicki w Polsce w latach 1944-1948. Studium z zakresu władzy, Warszawa 1981, s. 109-113. 
Pierwszym krokiem organizacyjnym było wznowienie działalności Komisji Szkolnej Episkopatu, pozostającej nadal organem nadzorczym do spraw kateche$z^{7}$. Organem doradczym Komisji był Zjazd Księży Wizytatorów, który regulował wszelkie sprawy organizacyjne, a za pomocą swoich podkomisji opracowywał programy i materiały katechetyczne. Na szczeblu diecezji nauczaniem religii zajmowały się Referaty Szkolne, które z czasem przekształciły się w Wydziały Nauki Chrześcijańskiej lub Wydziały Katechetyczne ${ }^{8}$.

W powojennej Polsce, poza różnorodnymi brakami, mocno zarysował się problem jakości kadry katechetycznej. Podnoszenie poziomu przygotowania katechetycznego rozpoczęto od stanu duchownego. W ramach studiów teologicznych odbywały się zajęcia z katechetyki, pedagogiki i psychologii. Jednakże, ze względu na brak specjalistów, wykłady z tych dziedzin prowadzone były przez profesorów dyscyplin pokrewnych ${ }^{9}$. Katecheci świeccy otrzymywali wykształcenie na wydziałach teologicznych Uniwersytetu Warszawskiego, Akademii Teologii Katolickiej, Katolickim Uniwersytecie Lubelskim, Uniwersytecie Jagiellońskim oraz w Instytutach Katechetycznych ${ }^{10}$ i ośrodkach prowadzących kursy wakacyjne ${ }^{11}$. Dlatego poziom wykształcenia, a co za tym idzie przygotowania do nauczania, katechetów był bardzo zróżnicowany. Zaraz po wojnie swoją działalność wznowiło Koło Księży Prefektów. Właśnie ich aktywność koncentrowała się przede wszystkim na czynnym włączeniu w system dokształcania, doskonalenia metodycznego i wychowawczo-duszpasterskiego katechetów świeckich ${ }^{12}$. Równocześnie zaczęły swoją działalność ogniska metodyczne, nazwane później ośrodkami metodycznymi, w których odbywało się dokształcanie i doskonalenie. Niektóre ośrodki działały bardzo prężnie, a swoje osiągnięcia metodyczne publikowały na łamach czasopism katechetycznych ${ }^{13}$. Ogólnopolskim organem prasowym Koła Księży Prefektów po zakończeniu wojny był „Przegląd Katechetyczny”, który ukazywał się od października 1946 roku do lipca 1948 roku. Czasopismo to postawiło sobie za cel podnoszenie fachowych kwalifikacji katechetów oraz uczestnictwo w ważnych wydarzeniach, które miały miejsce w polskiej katechezie ${ }^{14}$. Ośrodki metodyczne, nawiązujące do przedwojennej tradycji ognisk metodycznych, podejmujące tak energicznie problem doskonalenia, musiały w roku szkolnym

\footnotetext{
${ }^{7}$ Por. J. Doppke, Katechizacja w Polsce 1945-1990, Pelplin 1998, s. 54-55.

${ }^{8}$ Por. R. Harmaciński, Kursy przygotowujace katechetów w diecezji gorzowskiej w latach 1949-1972, w: J. Charytański (red.), Studia katechetyczne, t. 6, Warszawa 1987, s.14-16.

${ }^{9}$ Por. tamże, s. $14-16$.

${ }^{10}$ Por. F. Cieślak, Kształcenie katechetów w Polsce, AK 45 (1948) nr 3, s. 195-196.

${ }^{11}$ Por, R. Harmaciński, dz. cyt., s. 218-222,

${ }^{12}$ Kurs katechetyczny w Biatymstoku, Przegląd Katechetyczny 30 (1947) nr 11, s. 319.

${ }^{13}$ Koło prefektów we Wrocławiu posiadało własny biuletyn katechetyczny pt. „Informator”, który upowszechniał nowości dydaktyczne i pedagogiczne na Dolnym Śląsku. Por. Kurs katechetyczny, Przegląd Katechetyczny 31 (1948) nr 6-7, s. 160.

${ }^{14}$ Por. S. Wójcik, Katecheza w warunkach systemu totalitarnego. Na przykładzie Administracji Apostolskiej Dolnego Ślaska w latach 1945-1961, Wrocław 1995, s. 144-151.
} 
1947/1948 zaprzestać swojej działalności. Zawieszono również wydawanie „Przeglądu Katechetycznego". Przyczyną tego było nowe zarządzenie władz Polskiej Rzeczpospolitej Ludowej, które z jednej strony zarzucały katechetom brak kwalifikacji, a z drugiej likwidowały organizacje oraz pismo, mające na celu podnoszenie owych kwalifikacji ${ }^{15}$. W związku z zaistniałą sytuacją dokształcaniem i doskonaleniem zajęły się Referaty Katechetyczne w diecezjach. Propozycje formacji katechetów miały różny zasięg i przybierały różne kształty organizacyjne w poszczególnych diecezjach: konferencje katechetyczno-pedagogiczne, kwartalne spotkania metodyczne, dekanalne spotkania katechetyczne, dni skupienia, a czasem były to kilkutygodniowe kursy. Jak można zauważyć, to zróżnicowanie taktyczne i organizacyjne wpływało na ofertę programową proponowanych form. Starano się jednak, aby możliwie wiele form zawierało: lekcję pokazową z omówieniem i dyskusja, wymianę doświadczeń pracy katechetycznej i przekaz ważniejszych informacji dotyczących diecezji, Kościoła powszechnego i stanu katechizacji ${ }^{16}$. Wszystkie te działania miały na celu dokształcanie i doskonalenie katechetów, chociaż nie tak wszechstronne jak w ogniskach metodycznych. Przyczyny małego zakresu doskonalenia należy szukać w braku stabilizacji katechezy w Polsce Ludowej, czego przejawem było między innymi usunięcie lekcji religii z planu zajęć szkolnych. W roku szkolnym 1950/1951 religii nie umieszczono wśród przedmiotów szkolnych, a w następnym usunięto te zajęcia $\mathrm{z}$ większości szkó $1^{17}$. To utrudniało podjęcie stałych działań w kierunku doskonalenia, ponieważ miejsce samej katechezy nie było uzgodnione, co z kolei wpływało na formy realizacyjne procesu uczenia - nauczania.

Po usunięciu katechezy ze szkół, w latach 1952-1957 rozpoczęła się katecheza przy kościele, gdzie w warunkach parafialnych kształtowała się nowa forma nauczania religii ${ }^{18}$. Nowy model katechezy przeniósł na grunt kościelny pewne formy dydaktyczne i pedagogiczne, a te zmiany wymagały nowego spojrzenia na formację katechetów, aby uwzględnić innowacyjną formę katechezy ${ }^{19}$. Referaty Katechetyczne prowadziły równolegle formację metodyczną przez kursy instrukcyjno-informacyjne oraz formację duchową przez dni skupienia, konferencje ascetyczne.

${ }^{15}$ Por. S. Skuzo, Nauczanie religii w Polsce w świetle prawa państwowego po roku 1945, w: L. Balter (red.), Nowa ewangelizacja, Kolekcja Communio, nr 8, Poznań 1993, s. 118-121.

${ }^{16}$ Por. S. Wójcik, dz. cyt., s. 144.

${ }^{17}$ Por. Instrukcja z dnia 12 kwietnia 1950 roku w sprawie organizacji roku szkolnego 1950/51 w szkołach ogólnokształcacych stopnia podstawowego, D.U. MO $1950 \mathrm{nr} 8$ oraz S. Skuzo, dz. cyt., s. $118-121$.

${ }^{18}$ Por. J. Skarpetowski, Z powojennych dziejów katechizacji. Katechizacja zsynchronizowana (1952-1954), WAW 60 (1978), s. 92-97; W. Kubik, Rozwój myśli dydaktycznej w polskiej literaturze katechetycznej w latach 1895-1970, Warszawa 1987, s. 102-120.

${ }^{19}$ Por. L. Boreilo, Formazione permanente, w: Diozionario di Catechetica, Torino 1987, s. 99 i 499. 
Po powrocie religii do planu zajęć szkolnych ${ }^{20} \mathrm{w}$ roku $1956 \mathrm{w}$ formacji katechetów zwrócono uwagę na problematykę wychowawczą, a szczególnie na pogłębienie poznawanych treści katechetycznych w życiu codziennym, czyli w, postawach, decyzjach i wyborach. Poza tym zwrócono uwagę na problematykę wiary, problemy moralne i religijne młodzieży szkół zawodowych, jak również środowisko wychowawcze: rodzinę i szkołę ${ }^{21}$. Pomimo wielu trudności, jakie powodowały zarządzenia władz komunistycznych, oraz trudności z odnalezieniem się w sytuacji prawnej i oświatowej, katecheci w tym okresie podejmowali próby doskonalenia swojej pracy. $\mathrm{W}$ ramach tego doskonalenia poszukiwano ciekawych rozwiązań metodycznych różnych tematów katechetycznych na gruncie teorii i, praktyki ${ }^{22}$. Ich rozpowszechnianiem zajął się dwumiesięcznik „Katecheta”, wydawany od września 1957 roku. Na łamach tego pisma publikowano oryginalne propozycje jednostek katechetycznych, prezentowano nowe prądy i kierunki katechetyczne a katecheci mieli możliwość przedstawienia swoich przemyśleń, doświadczeń, propozycji rozwiązań metodycznych oraz dyskusji na temat struktury zajęć, podręczników, programu itp. ${ }^{23}$. W ten sposób dwumiesięcznik stał się forum doskonalenia zawodowego i sposobem dzielenia się osiagnięciami pracy. Nie odrodziły się w tym czasie struktury doskonalenia katechetów w ośrodkach metodycznych, które angażowałyby wszystkich uczących katechetów. Troska Kościoła skoncentrowała się przede wszystkim na kształceniu kadr, w minimalnym stopniu na ich doskonaleniu.

Po ponownym usunięciu religii ze szkół na początku lat sześćdziesiątych nastapiła zmiana w organizacji nauczania katechetycznego, a mianowicie nauczanie szkolne zastapiono parafialnym ${ }^{24}$. W tym okresie sprawa doskonalenia katechetów stała się podstawowym zadaniem Diecezjalnych Referatów Katechetycznych. Dodatkowo w omawianym okresie posoborowy ruch odnowy katechetycznej domagał się nowego spojrzenia na katechezę, a w konsekwencji na kształcenie i doskonalenie katechetów. Czasopisma „Katecheta”, a potem od 1967 roku „Studia Theologica Varsaviensia” przyczyniły się do zapoznania z ważniejszymi kierunkami posoborowej odnowy katechetycznej. Jednakże w praktyce wiele nowatorskich propozycji nie zostało przyjętych przez katechetów, gdyż nie

${ }^{20}$ Por. Okólnik NR 32 z dnia 11 grudnia 1956 r. w sprawie wykonania zarządzenia Ministra Oświaty z dnia 8 grudnia 1956 r. o nauczaniu religii w szkołach. D.U. MO 1956, nr 16, poz. $155-157$.

${ }^{21}$ Ogólnopolska konferencja katechetyczna, Katecheta 4 (1960) nr 6, s. 448.

${ }_{22}$ Por. J. Charytański, Z Dobra Nowinq w szkole, Warszawa 1991, s. 14-16.

${ }^{23}$ Por. J. Dajczak, Refleksje recenzyjne na temat katechizmów i podręczników do nauki religii wydanych w ostatnich latach w Polsce, Katecheta 2 (1958) nr 3, s. 203-217.

${ }^{24}$ Ustawa o rozwoju systemu oświaty $i$ wychowania, por. D.U. 1961, nr 32, poz. 160 oraz Zarzqdzenie Ministra w sprawie prowadzenia punktów katechetycznych, por. D.U. MO 1961, $\mathrm{nr}$ 10, poz. 124 i Instrukcja w sprawie rejestracji punktów katechetycznych, por. D.U. MO 1961, nr 11, poz. 144. 
widzieli oni takiej możliwości lub nie rozumieli zachodzących zmian ${ }^{25}$. Dojrzewała w Referatach Katechetycznych świadomość, że nie wystarczy prezentacja teoretyczna poprzez publikacje pewnych nowych opcji katechetycznych, programów czy celów i zadań. Organizowano zatem spotkania na szczeblu diecezjalnym i krajowym, aby przybliżyć postulaty odnowy katechezy oraz ukazać możliwości realizacyjne tych postulatów. W połowie lat sześćdziesiątych wysunięto potrzebę utworzenia ogólnopolskiego instytutu, który stałby się doktrynalno-metodycznym centrum katechetycznym w Polsce. Ośrodek taki nie powstał, natomiast utworzono katedrę katechetyki na Katolickim Uniwersytecie Lubelskim $^{26}$. W 1969 w Warszawie odbył się Ogólnopolski Kurs Katechetyczny, w ramach którego dokonano prezentacji Katechizmu Religii Katolickiej, podręcznika uwzględniającego zmienione warunki katechizacji, przemiany społeczne, problemy wieku rozwojowego, uchwały soborowe i ruch biblijno-liturgiczny ${ }^{27}$. W poszczególnych diecezjach organizowano na początku lub na końcu każdego kwartału roku szkolnego tak zwane Dni Katechetyczne ${ }^{28}$. W ich programie najczęściej znajdowały się referaty dotyczące posoborowej wizji katechezy, na przykład rola i miejsce Pisma Świętego w katechezie. Niekiedy w program Dni Katechetycznych włączona była katecheza pokazowa z możliwością omówienia i dyskusji nad koncepcją dydaktyczną. Całość kończyła prezentacja nowości wydawniczych. Inspiracji i tematów do rozważań czy dyskusji w proponowanych formach doskonalenia dostarczano katechetom z zewnattrz, nie były to problemy samych katechetów, toteż rzadko kiedy stanowiły przedmiot samodzielnych opracowań zespołów katechetycznych.

Podsumowując zauważyć trzeba, że doradztwo katechetyczne jako indywidualizowanie pracy i doskonalenie katechety w umiejętności dydaktyczne, metodyczne, wychowawcze czy teologiczne nie istniało w okresie Polski Ludowej ze względu na złożoną sytuację prawną i oświatową katechezy. Wyjątek stanowiły lata, gdy nauczanie religii odbywało się w szkole (były to lata 1945 do 1947 i 1957 do 1960). W omawianym okresie zwracano większą uwagę na formację duchową: dni skupienia, rekolekcje, konferencje ascetyczne i inne, ponieważ katecheza przyparafialna bardziej wymagała świadków wiary przygotowanych do ewangelizacji dzieci i młodzieży niż nauczycieli, rozumianych jako dydaktyków i wychowawców.

${ }^{25}$ Por. H. Pagiewski, Próba nowego polskiego katechizmu, Katecheta 14 (1970) nr 1, s. 13. Dość dobrze tę sytuację odzwierciedla wypowiedź jednego z katechetów: „Jestem zrozpaczony gdy chodzi o nowy program nauczania [...] wydaje mi się, że teraz nie umiem uczyć [...]. Ja bardzo się męczę, dzieci niewiele rozumieją [...]. Z przystępnej, zrozumiałej dla każdego człowieka nauki Chrystusa Pana powstała nowoczesna katecheza, której ja sam nie pojmuję, jak mam ją przekazywać dzieciom? Co ja mam zrobić" Por. R. Murawski, Potrzeba odnowy katechezy, Katecheta 18 (1974) nr 1, s. 20.

${ }^{26}$ Por. J. Doppke, dz. cyt., s. 127-128.

${ }^{27}$ Por. W. Kubik, Rozwój..., s. 170; J. Stroba, Geneza nowego programu katechetycznego, Katecheta 16 (1972) nr 4, s.142-148,

${ }^{28}$ Por. A. Kotlarski, Dni Katechetyczne, Katecheta 20 (1976) nr 1, s. 25-26. 


\section{Doskonalenie i doradztwo katechetyczne w III Rzeczypospolitej}

Katecheza jako jedna z podstawowych form posługi Słowa w Kościele w roku szkolnym 1990/91 ponownie znalazła swoje miejsce w szkole - uprzywilejowanym środowisku rozwoju młodego człowieka ${ }^{29}$. Od tego roku katecheci stali się nauczycielami w szkole, podejmującymi wszystkie obowiązki szkolne właściwe nauczycielom, uwzględniając aktualne przepisy prawne władz oświatowych dotyczace przygotowania i doskonalenia zawodowego nauczycieli. Przejście z parafii do szkoły dla katechety wiązało się z poszerzeniem dotychczasowych obowiązków, gdyż obok zadań przepowiadania doszły nowe o charakterze społecznym: praca w radzie pedagogicznej czy współdziałanie w rozwoju szkoły. Dostosowanie teorii dydaktycznych do przepowiadania i nauczania wymagało od katechety nowych umiejętności.

Instrukcja Ministra Edukacji Narodowej ${ }^{30}$, dotycząca powrotu religii do szkoły, wywołała spore protesty, a głosy krytyki dotyczyły głównie przygotowania dydaktycznego osób prowadzących zajęcia z religii. Wysuwano często zarzut słabego orientowania się katechetów w zagadnieniach dotyczących teorii nauczania i wychowania oraz zarzut nieuwzględniania podstawowych założeń procesu uczenia - nauczania ${ }^{31}$. W tej trudnej sytuacji katecheta potrzebował fachowego wsparcia, a takie mógł otrzymać między innymi od doradcy metodycznego. Okazją do powołania takiej funkcji dla katechetów stało się rozporządzenie Ministra Edukacji Narodowej w sprawie placówek doskonalenia nauczycieli ${ }^{32}$. W świetle tego rozporządzenia placówkami oświatowymi specjalizującymi się w prowadzeniu doskonalenia zawodowego nauczycieli są wojewódzkie ośrodki metodyczne, w strukturze których funkcjonują nauczyciele specjaliści zwani doradcami metodycznymi, reprezentujący różne specjalności i przedmioty nauczania. Zaistniała więc podstawa prawna, aby wśród nich znalazł swoje miejsce doradca nauczania religii.

Obowiazzki doradcy metodycznego powierzał wybranemu katechecie Kurator Oświaty na wniosek dyrektora Wydziału Katechetycznego Kurii Biskupiej i dyrektora szkoły, w której katecheta był zatrudniony. Katecheta doradca posiadał wykształcenie wyższe i kwalifikacje określone w tym rozporządzeniu oraz co najmniej pięcioletni staż pracy w szkole lub placówce oświatowej. Swoje obo-

${ }^{29}$ Por. Kongregacja do Spraw Wychowania Katolickiego, Świecki katolik świadkiem wiary w szkole, Poznań 1986, nr 14.

${ }^{30}$ Powrót nauki religii do szkoły dokonał się nie mocą ustawy, ale Instrukcji Ministra Edukacji Narodowej wydanej dnia 3 sierpnia 1990 r. na rok szkolny 1990/1991. Dopiero rok później - dnia 7 sierpnia 1991 r. Sejm Rzeczypospolitej przyjął ustawę oświatową regulującą nauczanie religii w szkołach publicznych. Rozporządzenie wykonawcze do ustawy wydał Minister Edukacji Narodowej dnia 14 kwietnia 1992 roku. Por. D.U. RP 1992, nr 36, poz. 329.

${ }^{31}$ Por. Ł. Bogacz-Rajda, Kontrowersje prasowe wokót powrotu katechezy do szkoły, Kraków 1994. s. $133-135$.

${ }^{32}$ Por. D.U. RP 1992, nr 63, poz. 317. 
wiązki szkolnego katechety realizował w ramach stosunku pracy z prawem obniżenia obowiązującego wymiaru godzin dydaktycznych, nie większym niż 2/3 tego wymiaru. Zadania doradcy powierzane były na czas określony, nie dłuższy niż trzy lata, z prawem przedłużenia. Organizacja pracy nauczyciela doradcy była analogiczna do systemu pracy doradców innych przedmiotów, z zachowaniem specyfiki przedmiotu.

Ponieważ funkcja doradcy nauczyciela religii była stosunkowo nowym zjawiskiem, jego praca nie musiała wyglądać jednolicie we wszystkich diecezjach, mogła przybierać różne formy działań wspomagających katechetę oraz realizować różne zadania dodatkowe ${ }^{33}$. Najczęściej nauczyciel doradca podejmował swoją funkcję w ramach szczegółowych zadań określanych mu przez placówkę doskonalenia w ramach stosunku pracy ${ }^{34}$. Do charakterystycznych zadań doradcy należały:

1) diagnozowanie stanu kwalifikacji nauczycieli i określanie potrzeb w za kresie ich doskonalenia,

2) organizowanie i prowadzenie doradztwa merytorycznego i metodycznego na terenie województwa, ze szczególnym uwzględnieniem nauczycieli rozpoczynających pracę,

3) udostępnianie własnego warsztatu w ramach lekcji otwartych,

4) uczestniczenie w lekcjach prowadzonych przez nauczycieli,

5) upowszechnianie nowych metod, technik i środków, wspieranie działań innowacyjnych w oświacie,

6) udział w przygotowaniu nauczycieli do procedury zdobywania stopni specjalizacji zawodowych,

7) merytoryczne wspieranie zmian w oświacie, na przykład programowych,

8) opracowywanie materiałów metodycznych służących doskonaleniu pracy nauczycieli,

9) prowadzenie form doskonalenia: konferencje, konsultacje,

10) prowadzenie pracowni w szkole, w której doradca jest zatrudniony,

11) doskonalenie własnych kwalifikacji zawodowych.

W obowiązkach szczegółowych doradcy zauważyć można, że podstawowym zadaniem doradcy, choć różnie realizowanym w diecezjach, jest udzielanie katechecie porady, pomocy oraz inicjowanie różnych form doskonalenia. W organizacji doradztwa istniał podział na rejony metodyczne w ramach danego województwa wchodzącego w skład diecezji. Wyznaczało to określone ramy te-

${ }^{33}$ Por. Z. Molęda, Możliwości aktywizowania katechetów w opinii doradcy metodycznego katechetów w archidiecezji lubelskiej, w: S. Kulpaczyński (red.), Aktywizowanie katechizowanych, Lublin 1997, s. 130-135.

${ }^{34}$ Por. B. Pojawa, Możliwości aktywizacji katechetów w opinii doradcy metodycznego, w: S. Kulpaczyński (red.), dz. cyt., s. 146-147. 
rytorialne, w których tworzone były jednostki organizacyjne, tak zwane zespoły metodyczne ${ }^{35}$. Wydawało się korzystnym rozwiązaniem, aby wyżej wymienione rejony metodyczne pokrywały się terytorialnie z administracją kościelną, to jest dekanatem, czyli obszarem dziesięciu parafii ${ }^{36}$.

Taka sytuacja prawnego powoływania doradców utrzymywała się do czasu wprowadzenia pierwszego etapu reformy edukacji, czyli decentralizacji systemu oświaty w roku 1999. W tym okresie urzędy gminne i powiatowe stały się odpowiedzialne za poziom edukacji nauczycieli, placówek i uczniów. W gestii gminy i powiatu leży powoływanie doradców i określanie zakresu ich obowiązków oraz form realizacji zadań doradczych. Rozwiązania lokalne bywają często uwarunkowane sytuacją ekonomiczną i polityczną danej gminy, stąd wydają się rozwiązaniami niezbyt szczęśliwymi. Poza tym wydawane z częstotliwością kilku projektów rozporządzeń w ciągu półrocza, określających zadania ośrodków metodycznych i ich pracowników, nie pomagają w porządkowaniu i normowaniu zagadnień oświatowych na poziomie gminy. Sytuacja taka wymaga od diecezjalnych referatów katechetycznych współpracy z urzędami gminnymi, powiatowymi i starostwami oraz czuwania nad pracą samych doradców, przynajmniej w zakresie terenu działań i powierzanych zadań.

Niezależnie od rozporządzeń stwierdzić należy, że specjalistyczna pomoc, jaką niesie doradztwo pedagogiczne dla nauczycieli religii, powinna mieć charakter działań celowych i opartych na odpowiednio skonstruowanym planie rocznym. Aby ta praca doradcy była właściwa i skuteczna, powinna być poprzedzona rozeznaniem środowiska katechetycznego. Taka analiza czy diagnoza środowiska pozwoli doradcy dostosować ofertę doskonalenia do rzeczywistych potrzeb nauczycieli religii ${ }^{37}$. Istotne jest gromadzenie takich informacji, jak wykształcenie, udział w doskonaleniu, staż, miejsce i warunki pracy nauczyciela. Właściwa analiza danych personalnych nauczycieli religii również pomaga doradcy dostosować ofertę do faktycznych potrzeb nauczycieli oraz ułożyć adekwatny plan działalności doradczej ${ }^{38}$.

Poza tym prowadzona przez doradców diagnoza pozwoliła dostosować ofertę doskonalenia do rzeczywistych potrzeb środowiska nauczycieli religii, aczkolwiek w ramach wskazań szczegółowych Ministra Edukacji Narodowej dla placówek doskonalenia $^{39}$. Ponieważ oferta doradcza kierowana była do konkretnej grupy katechetów, musiała różnić się co do formy i treści w zależności od potrzeb środowiska.

Szczególna grupa katechetów, do których adresowane było doradztwo, to nauczyciele rozpoczynający pracę w szkole. Ponieważ ich przygotowanie do ka-

\footnotetext{
${ }^{35}$ Por. D.U, MEN 1990, nr 5, poz. 26.

${ }^{36}$ Por. W. Kubik, Permanentne doksztatcanie katechetów, CT 63 (1993) nr 3, s. 122-130.

${ }^{37}$ Por. D.U. RP 1991, nr 98, poz. 439.

${ }^{38}$ Por. S. Irla, Katecheta - doradca metodyczny, w: Dzisiejszy katecheta, stan aktualny $i$ wyzwania, Kraków 2002, s. 220-223.

${ }^{39}$ Por. D.U. RP 1991, nr 98, poz. 439.
} 
techezy było bardzo zróżnicowane, dlatego w systemie dokształcania i doskonalenia uwzględnić należało uzupełnienie braków systemu kształcenia podstawowe$\mathrm{go}^{40}$. W takim ujęciu wydaje się, że doradztwo było nastawione na zaspokajanie praktycznych potrzeb katechetów i funkcjonowało na poziomie korekty usprawniającej lub likwidującej rozpoznane nieprawidłowości działań dydaktycznych. Ten styl wspomagania katechety nie zadawalał doradcy, a tym bardziej placówki doskonalenia, której zadaniem jest rozwój zawodowy nauczyciela i twórcze poszukiwanie własnego stylu nauczania. Doradca swoją ofertę kierował do tych, którzy chcieli wzbogacić swe kwalifikacje i kompetencje nauczyciela religii w zakresie sztuki nauczania - katechizacji. W trosce o to, by katecheta nie był tylko odbiorcą prezentowanych informacji, doradcy starali się zainicjować wśród katechetów dyskusję z wymianą poglądów na zaprezentowany temat oraz wymianę doświadczeń pedagogicznych. Tego typu zaproszenia kierowane były do nauczycieli religii z długoletnim stażem, którym, jak wszystkim nauczycielom, zagraża w pracy rutyna działań dydaktycznych przez upowszechnienie raz przyjętej postawy, jeśli ta okazała się skuteczna w pracy z uczniem ${ }^{41}$. Doradca w swej ofercie spotkań metodycznych starał się pobudzić do otwartości, krytycyzmu i twórczych poszukiwań dla swojej pracy dydaktycznej przez wspólną refleksję nad hospitowanymi zajęciami.

Proponowane formy organizacyjnie nie odbiegały od propozycji doradców innych przedmiotów. Najbardziej rozpowszechnioną formą były konferencje i konsultacje. Dawały one możliwość spotkania się i jednocześnie przekazu najważniejszych informacji w dużej grupie nauczycieli. Dobrze było, gdy zespół katechetów z jednego dekanatu stanowił zespół metodyczny wspólnie uczestniczący w konsultacji zbiorowej lub, jeszcze korzystniej, był zespołem samokształceniowym pracującym pod kierunkiem doradcy. Od doradcy oczekiwano dobrego przygotowania, komunikatywności, sprawności w atrakcyjnym przygotowaniu spotkania i pełnego zaangażowania ${ }^{42}$. Najefektywniejszą formą doradztwa, zalecaną przez Ministerstwo Edukacji Narodowej i bardzo cenioną w ośrodkach metodycznych, były konsultacje indywidualne. Przynosiły one wymierne korzyści konkretnemu katechecie, ponieważ wpływały na pogłębienie jego aktywności katechetycznej a doradcy umożliwiały szybszą i skuteczniejszą diagnozę potrzeb, nie wspominając o relacji personalnej, która korzystnie wpływała na kształtowanie dalszej współpracy ${ }^{43}$. Inne oferowane formy to: kursy doskonalące,

${ }^{40}$ Por. M. Nowacka, Zadania i kierunki pracy katechetycznego doradcy, w: S. Kulpaczyński (red.), dz. cyt., s. 127-130.

${ }^{41}$ Zob. M. Majewski, Pedagogiczno-dydaktyczne wartości katechezy integralnej, Kraków 1995, s. 158.

${ }^{42}$ Por. E. Ossewska, I ogólnopolskie warsztaty metodyczne dla nauczycieli doradców $i$ konsultantów ds. katechezy, Katecheta 41 (1997) nr 2, s. 77-78.

${ }^{43}$ Por. A. Lubczyk, Doradca metodyczny - osoba wspótpracujaca z katecheta, w: S. Kulpaczyński (red.), dz. cyt., s. 154-158; M. Śnieżyński, Katecheta w szkole. Poradnik pedagogiczny, Kraków 1994, s. 181-182. 
warsztaty, seminaria itp. Różnorodność tematyczna tych form i organizacja zajęć świadczy o zapotrzebowaniu na doradztwo oraz złożoności sytuacji katechezy w warunkach szkolnych. Wszystkie te propozycje doskonalenia były dla doradcy początkiem procesu wspomagania. Chcąc się dowiedzieć o skuteczności swych działań, każdą z propozycji poddawał ewaluacji, aby lepiej planować swą ofertę na przyszłość, by służyła katechetom szkolnym a przez nich uczniom. Zarysowany tu obraz doradztwa domagał się od pełniącego tę funkcję nauczyciela religii stałej troski o aktualizacje swych kompetencji przez samokształcenie i udział $\mathrm{w}$ formach doskonalenia zawodowego ${ }^{44}$.

Z przedstawionego powyżej zarysu działań doradcy pedagogicznego dla nauczycieli religii można wywnioskować, że są one częścią doskonalenia zawodowego proponowanego przez Kościół w ramach tak zwanej formacji permanentnej w okresie Polski Ludowej. Kościół w ramach katechetycznej formacji permanentnej proponuje również doskonalenie dydaktyczne, stąd powołanie funkcji doradcy metodycznego było ubogaceniem formacji proponowanej przez Kościół.

\section{Główne obszary zmian w doradztwie katechetycznym}

Obraz katechety w ostatnich siedemnastu latach zmienił się, katecheta szkolny poszerzył swoje kompetencje jako nauczyciel. Obecnie nierzadko posiada przygotowanie zawodowe do nauczania dwóch przedmiotów oraz kurs kwalifikacyjny umożliwiający prowadzenie na terenie szkoły zajęć dodatkowych. Te sytuacje skłaniają doradców do przemyślanej i atrakcyjnej oferty doskonalącej i doradczej dostosowanej do możliwości i oczekiwań nauczyciela religii. Dlatego doradcy starają się odpowiedzieć na wymagania czasu i wprowadzają nowe formy i treści do projektów doskonalenia zawodowego.

W kolejnych latach III Rzeczypospolitej zachodziły zmiany w rozumieniu doradztwa, jak również w sposobie działań doradczych, zmieniały się również potrzeby katechetów zarówno co do treści, jak i co do formy doskonalenia. Doradcy starali się dostosować swoją działalność do oczekiwań i potrzeb katechetów. Zanim dokonana zostanie analiza zachodzących zmian i próba ustalenia pewnych ich kierunków, należy zadać pytanie, czy katecheta szkolny, coraz bardziej udoskonalony przez różne kursy i ośrodki szkoleniowe, widzi potrzebę istnienia doradztwa dla nauczycieli religii.

W roku szkolnym 2000/2001 przeprowadzono badania wśród katechetów wybranych diecezji celem pozyskania informacji o postrzeganiu pracy doradcy oraz zmian w jego działalności ${ }^{45}$. Znamienne jest to, że chociaż doradztwo

\footnotetext{
${ }^{44}$ Por. D.U. MEN 1990, nr 5, poz. 26.

${ }^{45}$ Badania własne przeprowadzone przez autorkę w roku szkolnym 2000/2001 w pięciu diecezjach polskich, przebadano wówczas 220 nauczycieli i 25 doradców metodycznych do nauczania religii.
} 
w badanym roku szkolnym istniało od ok. pięciu lat (z wyjątkiem jednej diecezji - 8 lat) wśród katechetów było powszechnie znane. Na pytanie, czy dostrzegaja potrzebę dalszego funkcjonowania doradztwa pedagogicznego dla katechetów, wśród badanych nauczycieli nie odnotowano odpowiedzi negatywnej. Potrzebę doradztwa a także chęć dalszej współpracy z doradcą zadeklarowało 189 nauczycieli religii (95\%), natomiast 9 badanych nie udzieliło żadnej odpowiedzi.

Kolejne pytanie adresowane do katechety dotyczyło zmian w sposobie i treści doskonalenia. Odpowiedzi na to pytanie prezentuje tabela 1.

Tabela 1. Zmiany dostrzeżone przez katechetów w systemie doradztwa w latach 1992-2000

\begin{tabular}{|c|l|c|c|}
\hline Lp. & \multicolumn{1}{|c|}{ Dostrzeżone obszary zmian } & $\mathrm{N}=198$ & $\%$ \\
\hline 1 & oferta doskonalenia zawodowego & 126 & 64 \\
\hline 2 & treść doradztwa & 81 & 41 \\
\hline 3 & organizacja spotkań & 63 & 32 \\
\hline 4 & diagnozowanie potrzeb katechetów & 33 & 17 \\
\hline 5 & nic się nie zmieniło & 32 & 16 \\
\hline 6 & częstotliwość konsultacji indywidualnych z doradcą & 13 & 6 \\
\hline 7 & inne & 5 & 2 \\
\hline
\end{tabular}

${ }^{*}$ Możliwość wielokrotnego wyboru i wyniki nie sumuja się do $100 \%$

$\mathrm{Z}$ tabeli 1 wynika, że wielu respondentów dostrzegło zmiany, dokonujące się w systemie doradztwa dla nauczycieli religii. Żadnych zmian nie dostrzegł co szósty z badanych katechetów. Największa ilość respondentów zauważyła zmiany w ofercie doskonalenia zawodowego $-64 \%$ badanych. Drugim obszarem zmian podkreślanym przez katechetów jest treść doradztwa $-41 \%$ badanych. Korzystniejszą zmianę w organizacji konferencji i konsultacji zespołowych dostrzegło - 32\%. Inne obszary zmian w systemie doradztwa zauważone przez nauczycieli religii to diagnozowanie potrzeb środowiska katechetycznego (17\%) oraz zwiększenie ilości konsultacji indywidualnych (6\%).

Czy nauczyciele religii widzą potrzebę dalszych zmian w systemie doradztwa i jakie obszary działań doradczych powinny jeszcze ulec zmianie? Odpowiedź na to pytanie zawiera tabela 2 . 
Tabela 2. Obszary działań doradczych, które powinny ulec zmianie. Propozycja katechetów

\begin{tabular}{|c|l|c|c|}
\hline Lp. & \multicolumn{1}{|c|}{ Działania doradcze, które powinny ulec zmianie } & $\mathrm{N}=198$ & $\%$ \\
\hline 1 & liczba opracowań pisemnych / materiałów praktycznych & 181 & 91 \\
\hline 2 & oferta doskonalenia zawodowego & 75 & 38 \\
\hline 3 & organizacja spotkań & 23 & 12 \\
\hline 4 & tematyka spotkań - treści teologiczne & 6 & 3 \\
\hline
\end{tabular}

*Możliwość wielokrotnego wyboru i wyniki nie sumuja się do $100 \%$

Analizując tabelę 2, zauważa się, że katecheci przede wszystkim oczekują większej praktyczności zawodowej w doskonaleniu a mniej refleksji teoretycznej (91\% respondentów oczekuje opracowań pisemnych, zawierających praktyczny materiał do wykorzystania na zajęciach dydaktycznych lub wychowawczych). Zastanawiający jest wysoki wskaźnik zapotrzebowania katechetów na zwiększenie pisemnych opracowań. Można założyć, że to zapotrzebowanie jest wynikiem oczekiwania doraźnej pomocy w postaci przykładów rozwiązań dydaktycznych, wzorców zachowań, które bez szczególnych przekształceń można zastosować w praktyce szkolnej. Nie jest zjawiskiem pożądanym ciagge oczekiwanie nauczyciela, by doradca dostarczał gotowych pomysłów, wzorów, schematów działań wychowawczych czy dydaktycznych. Świadczyć to może o bardzo wąskim praktycyzmie nauczyciela i doradcy. Bezkrytyczne zaspakajanie takich oczekiwań prowadzi do negatywnych zjawisk w zawodowym rozwoju, na przykład:

- obniżenia krytycyzmu i analizy własnej działalności edukacyjnej,

- osłabienia motywacji do modernizowania warsztatu pracy,

- braku samodzielności myślenia,

- braku zainteresowania nauczycieli innowacjami pedagogicznymi a w konsekwencji niedostrzeganie potrzeby współpracy z doradcą lub twórczymi nauczycielami ${ }^{46}$.

Poza tym opracowania pisemne są działaniami z obszaru działań pośrednich i nie należą do priorytetowych zadań doradcy pedagogicznego.

Co trzeci badany katecheta chce, aby oferta doskonaląca zmieniała się, to jest była aktualizowana w miarę zmieniających się potrzeb i wymagań pracodawców. Natomiast co dziewiąty respondent oczekuje zmian w sferze organizacyjnej doradztwa. Oba punkty są interesujące, ponieważ doradztwo pedagogiczne, niesie wiele różnych możliwości pomocy nauczycielowi podczas całego okresu zatrudnienia, szczególnie poprzez formy zindywidualizowane doradztwa. Doradca

${ }^{46}$ Por. J. P. Sawiński, Logika rozwoju zawodowego nauczyciela, Edukacja i Dialog 1 (1997), s. $22-32$. 
pedagogiczny spełnia swoją rolę, gdy pobudza nauczyciela do refleksji i krytyki własnego warsztatu pracy, prowadzi do analizowania własnej postawy i stylu działania edukacyjnego, predyspozycji zawodowych, możliwości i faktycznych umiejętności oraz uczy projektowania zmian, odpowiedzialności i samooceny ${ }^{47}$. Bywa, że sam nauczyciel uniemożliwi taką formę pomocy, między innymi poprzez nierefleksyjność, niską świadomość własnych braków oraz nieumiejętność werbalizacji własnych potrzeb. Ma to miejsce wtedy, gdy kontakt z doradcą jest wymuszony przez wymagania ministerstwa lub dyrektorów placówek oświato$w_{y c h}{ }^{48}$. Indywidualizacja posługi doradczej jest dużą szansą dla rozwoju katechety szkolnego. Poszerzenia oferty o treści teologiczne oczekuje zaledwie 3\% respondentów.

Analiza wyników badań przedstawionych w tabeli 2 stymuluje do postawienia kolejnych pytań: co jest przyczyną takich zapotrzebowań wśród nauczycieli religii, czy jest nią dość ograniczona umiejętność rozwiązywania problemów dydaktyczno-wychowawczych? Jeżeli tak, to czy nabywanie tej umiejętności nie powinno znaleźć się w wytycznych przyszłych działań doradczych? Pewnym wskaźnikiem kierunku modyfikacji w systemie doradztwa dla nauczycieli religii są motywy, dla których katecheci chcą nadal korzystać z doradztwa pedagogicznego. Motywy korzystania z działań doradczych ilustruje tabela 3.

Tabela 3. Motywy korzystania w przyszłości z doradztwa pedagogicznego

\begin{tabular}{|c|l|c|c|}
\hline Lp. & \multicolumn{1}{|c|}{ Motywy korzystania z doradztwa pedagogicznego } & N = 198 & $100 \%$ \\
\hline 1 & doskonalenie warsztatu pracy & 57 & 29 \\
\hline 2 & podniesienie kompetencji nauczycielskich & 28 & 14 \\
\hline 3 & zwiększenie efektywności działań edukacyjnych & 27 & 14 \\
\hline 4 & rozwój zawodowy & 22 & 11 \\
\hline 5 & brak uzasadnienia & 21 & 11 \\
\hline 6 & inne & 18 & 9 \\
\hline 7 & obowiązek nauczyciela & 9 & 4 \\
\hline 8 & brak odpowiedzi & 9 & 5 \\
\hline 9 & poznanie przepisów prawnych, oświatowych i kościelnych & 7 & 3 \\
\hline & $\quad$ RAZEM & 198 & 100 \\
\hline
\end{tabular}

${ }^{47}$ Por. J. P. Sawiński, Samoocena nauczyciela: tak i nie, Nowa Szkoła 53 (1997) nr 2, s. 4-6.

${ }^{48}$ Tamże. 
Racje, dla których katecheci zamierzają korzystać z doradztwa pedagogicznego, są różnorodne. Najczęstszym powodem jest chęć doskonalenia warsztatu pracy nauczyciela religii (29\%). Podniesienie kompetencji katechety jako nauczyciela-wychowawcy podaje jako motyw 14\% respondentów, z tą motywacją związana jest efektywność działań edukacyjnych, którą podaje również 14\% katechetów. Działania doradcze jako pomoc w rozwoju zawodowym zauważa $11 \%$ respondentów. Inne przyczyny korzystania z doradztwa to: pomoc $\mathrm{w}$ rozwiązywaniu problemów (3 osoby), pomoc w wypełnieniu powołania katechetycznego (5 osób), ponieważ jest to interesujące spotkanie ( 2 osoby), z potrzeby dowiedzenia się czegoś nowego (4 osoby). Dziwi natomiast fakt, że nie podaje uzasadnienia korzystania $\mathrm{z}$ doradztwa pedagogicznego co dziesiąty z badanych katechetów.

Inaczej obszary zmian postrzegają doradcy nauczycieli religii. Główne źródło przemian w doradztwie pedagogicznym upatrują w reformie oświaty, która zmieniła dotychczasowe zasady funkcjonowania doradztwa. Doradcy nakreślili tylko główne obszary, które wymagają pogłębienia lub gruntownej zmiany w funkcjonowaniu doradztwa. Propozycje obszarów przemian w doradztwie ilustruje tabela 4.

Tabela 4. Propozycje zmian w doradztwie według doradców

\begin{tabular}{|c|l|c|}
\hline Lp. & \multicolumn{1}{|c|}{ Obszary przyszłych działań doradczych } & $\mathrm{N}=23$ \\
\hline 1 & diagnoza środowiska katechetycznego & 17 \\
\hline 2 & pobudzanie katechetów do kreatywności & 11 \\
\hline 3 & współpraca z instytucjami wspomagającymi & 10 \\
\hline 4 & motywowanie nauczyciela do rozwoju zawodowego & 8 \\
\hline 5 & integracja środowiska katechetycznego w diecezji & 3 \\
\hline
\end{tabular}

* Możliwość wielokrotnego wyboru i wyniki nie sumuja się do 23.

Doradcy dostrzegają przede wszystkim konieczność diagnozowania środowiska katechetów, aby działania doradcze odpowiadały na zapotrzebowanie nauczycieli. Ważnym obszarem działań doradczych, wymagającym namysłu, jest pobudzanie nauczycieli religii do twórczości dydaktyczno-wychowawczej. Tę kwestię zaznacza połowa badanych doradców. Drugim ważnym obszarem wskazywanych przemian w systemie doradztwa jest współpraca z instytucjami wspomagającymi doradztwo, takimi jak: kuria biskupia, uczelnia wyższa, wydział oświaty czy kuratorium, bądź w przyszłości inne placówki, które warunkować będą funkcjonowanie doradztwa. Interesująca propozycją wydaje się zaplanowanie działań motywujących katechetów do rozwoju zawodowego (8 doradców 
na 23). Również ciekawą propozycją jest integracja katechetów w danej diecezji wokół wspólnego dzieła, zadania czy uroczystości, które dostrzega, jako obszar nowych działań doradczych, trzech respondentów.

Ankieta adresowana do katechetów i doradców zawierała również pytania o tematykę spotkań z doradcą oraz formy ich realizacji. Analizując bardzo pobieżnie oferty doskonalenia zawodowego w kategorii religia na przestrzeni 17 lat, zobaczyć można ewolucyjność proponowanych form i treści w kolejnych latach. Ewolucyjność form wyraża się przede wszystkim w poszerzaniu oferty od spotkań ogólnych, poprzez konsultacje, do małych i większych form warsztatowych. A ewolucyjność treści w dążeniu do zagadnień coraz bardziej szczegółowych i specjalistycznych, bardziej wychowawczych niż przedmiotowych. W proponowanych formach i treściach doskonalenia przeważają zagadnienia praktyczne, rzadziej spotykaną formą jest wykład. Zwiększenie treści metodycznych związane jest z reformą oświaty, która wymagała od doradcy szybkich reakcji na pojawiające się pytania i zagubienie nauczycieli religii wśród nowości edukacyjnych. Istnieje jednak obawa, że propozycja działań praktycznych, jako reakcja na pojawiające się nowości w edukacji, pominęła stadium diagnozy. Wtedy proponowane działania doskonalące byłyby rozwiązaniami pozornymi, nieujmującymi źródła problemu nauczyciela religii.

Podsumowując można zauważyć, że zarówno doradcy, jak i katecheci zauważają potrzebę modyfikacji i przemian w funkcjonowaniu doradztwa dla nauczycieli religii. W propozycjach zmian katecheci podaja jednostkowe działania doradcze, natomiast doradcy dostrzegają zbiór różnorodnych działań doradczych, które usprawniłyby i polepszyły jakość doradztwa dla nauczycieli religii. Na podkreślenie zasługuje otwartość obu grup na zmieniającą się rzeczywistość oświatową.

\section{Współczesne oczekiwania wobec doradztwa metodycznego}

Aktualnie doradztwo metodyczne jest ,piętą achillesową” polskiej oświaty. Przepisy prawne sprawiły, że rozmyła się odpowiedzialność za jego organizację. W szkole rozwijają się różne formy doradztwa, tak zwane doradztwo partnerskie (coaching partnerski) wykonywane przez kolegę albo doradztwo zespołowe benchmarking (uczenie się na sukcesach najlepszych) ${ }^{49}$. Coraz częściej dotychczasowe doradztwo metodyczne określa się mianem „doradztwo eksperckie”, wskazując na jego zewnętrzny w stosunku do szkoły charakter.

Podczas VI konferencji (listopad 2005 r.), zorganizowanej przez Centralny Ośrodek Doskonalenia Nauczycieli (CODN), na temat regionalnych systemów doskonalenia nauczycieli wiele dyskutowano o potrzebie lepszego „umocowa-

${ }^{49}$ Por. D. Elsner, Doskonalenie kierowania placówkq oświatowq. Wokót nowych pojęć i znaczeń, Chorzów 1999, s. 155-188. 
nia" prawnego doradztwa metodycznego, szczególnie przedmiotowego. Pierwszą i najistotniejszą konkluzją z tej konferencji była potrzeba integracji działań pomiędzy jednostkami samorządu terytorialnego, kuratoriami oświaty, wojewódzkimi placówkami doskonalenia nauczycieli, okręgowymi komisjami egzaminacyjnymi, bibliotekami pedagogicznymi i innymi instytucjami zajmującymi się edukacją. Wiele też zależy od samych nauczycieli, to oni powinni sami zgłaszać potrzebę zatrudnienia doradców ${ }^{50}$, chociaż nie bez znaczenia jest dobra wola samorządów terytorialnych.

Podkreślono, że bez doradztwa wspomagającego zastosowanie nowej wiedzy i umiejętności, praktyczne efekty ich wdrożenia sięgają często zaledwie 10\%, wsparcie nauczyciela doradztwem zwiększa efekty wdrożenia nawet do $75 \%$.

Pomimo wielu trudności w zafunkcjonowaniu doradztwa nauczyciele odczuwają współcześnie jego przydatność a nawet niezbędność w wielu sytuacjach edukacyjnych. Oto ich obecnie najczęstsze wypowiedzi:

- mnogość problemów w pracy nauczyciela, a zatem potrzeba wsparcia i konsultacji przy ich rozwiązywaniu,

- szczególnie młodzi nauczyciele potrzebują pomocy (np.: przy sporządzaniu planów wynikowych, wyborze podręczników, budowaniu PSO, opracowywaniu testów, doborze metod), doradca jest bazą nowości metodycznych, szczególnie dla szkół wiejskich,

- istnieje ciagła potrzeba doskonalenia zawodowego nauczyciela i jego rozwoju, trzeba wymieniać się spostrzeżeniami, w dobie szybkiego rozwoju metod nauczania nauczyciel potrzebuje na każdym etapie swojej pracy pomocy, nowych pomysłów, poczucia bezpieczeństwa w obecności doradcy,

- nauczyciel, który chce dobrze pracować, musi mieć możliwość dzielenia się uwagami, dyskusji, uzyskiwania odpowiedzi i ma to sens, gdy doradca jest kompetentny, posiadający doświadczenie i sukcesy w pracy z uczniami,

- kiedy zawodzi Internet doradca jest dostępny nawet przez telefon,

- potrzebna jest osobista konsultacja w sprawach metodycznych z doradca, bo dyrektor nie jest specjalistą od wszystkiego, potrzebne są lekcje pokazowe, spotkania z doradcą pozwalają na wymianę doświadczeń i na inne spojrzenie na swoje zajęcia dydaktyczne, na studiach jest mało metodyki nauczania,

- w związku z nadmiarem dokumentacji nauczyciele pogubili się w pracy, nie rozróżniają podstawowych obowiązków i dlatego potrzebują pomocy doradcy, swojego przewodnika po nowościach metodycznych i w rozwiązywaniu różnego rodzaju problemów warsztatowych.

${ }^{50}$ Zob. M. Kułak, Doradcy do reanimacji, Głos Nauczycielski 49 (2005) 6. 
Współcześnie również rosną wymagania co do doradztwa i pracy doradcy. Oto przykładowe wypowiedzi:

- potrzebna jest osoba koordynująca działania nauczycieli danego przedmiotu we wszystkich szkołach,

- realia pracy w każdej szkole są inne i dlatego potrzebna jest pomoc doradcy w miejscu pracy nauczyciela,

- aby był blisko - na miejscu, żeby był dyspozycyjny i działał planowo, a nie tylko sporadycznie, żeby przynajmniej dwa razy w roku spotkał się z nauczycielem przedmiotu,

- żeby był możliwy kontakt elektroniczny, internetowy i możliwość częstszych konsultacji indywidualnych,

- żeby nie prowadził spotkań ex cathedra, więcej bywał na lekcjach, prowadził sam lekcje otwarte,

- żeby pomógł przy organizacji konkursów międzyszkolnych i organizował częściej spotkania w gronie specjalistów,

- lepiej informował o dyżurach, kontaktach i możliwych formach współpracy,

- nie ograniczał doradztwa tylko do konferencji i warsztatów, częściej kontaktował się z nauczycielem, zespołem przedmiotowym w miejscu pracy, zapoznawał z nowymi metodami praktycznie, pomagał przy układaniu testów, pisaniu konspektów, planów wynikowych itp., nie organizował wyłącznie konferencji promujących wydawców,

Aktualnie nie dysponuję wypowiedziami nauczycieli religii, ale sądzę, że byłyby podobne do wyżej przytoczonych z konferencji CODN. Poza tym trzeba dostrzec także specyficzny element posługi doradcy dla nauczycieli religii. Ich działania powinny być częścią doskonalenia zawodowego katechetów, proponowanego przez Kościół w ramach tak zwanej formacji permanentnej. Formacja permanentna zakłada doskonalenie osobowe, pedagogiczne i teologiczne katechety. W sytuacji powrotu religii do szkół wydaje się, że powołanie funkcji doradcy metodycznego było ubogaceniem formacji proponowanej przez Kościół. Dlatego te działania powinny być zharmonizowane z całokształtem działań formacyjnych w diecezji. Może bardziej w obecnym czasie potrzebna jest jedna, spójna myśl formacyjna, obejmująca diecezję, w skład w której wchodzi wiele gmin i powiatów, realizujących różne aspekty doskonalenia zawodowego. Właściwie określona relacja między Wydziałem Katechetycznym a doradztwem warunkować będzie owocność doskonalenia zawodowego i osobowego katechetów, proponowaną w ramach formacji permanentnej danej diecezji. 


\section{Changes in pedagogical consultancy for religion education teachers at the turn of the millennia (Summary)}

The article consists of five parts showing the pedagogical consultancy phenomenon and its evolution over the last fifty years. The first part analyses the idea of consultancy and its understanding. The second part discusses the situation of religion education teachers consultancy and the ways its execution under the regime of the socialist country. The third part contains the synthesis of advisory actions after 1989 in Poland. It shows a fast development of forms and methods of advisory actions and their effect on religion teachers who have become school teachers since 1990. The fourth part shows the evolution of consultancy on the grounds of one's own research. The last part determines the contemporary expectations for consultancy and the possibilities to meet them. 